\title{
Human thyroid tumours, the puzzling lessons from E7 and RET/PTC3 transgenic mice
}

\author{
L Jin ${ }^{*, 1}$, A Burniat', J-E Dumont', F Miot', B Corvilain' and B Franc ${ }^{2}$ \\ 'Institut de Recherche Interdisciplinaire (IRIBHM), Faculté de Médecine, Université Libre de Bruxelles (ULB), Campus Erasme, Route de Lennik 808, \\ B 1070 Bruxelles, Belgique; ${ }^{2}$ Hôpital Ambroise Paré (APHP), Université de Versailles Saint Quentin en Yvelines, Service d'Anatomie Pathologique, 9 Av., \\ Charles de Gaulle, F-92 104 Boulogne, France
}

Human rearranged RET/PTC3 (papillary thyroid carcinoma) proto-oncogene and high-risk human papillomavirus (HPV) type I6 E7 oncogene induces in the mouse a neoplastic transformation of thyroid follicular cells. We present a detailed immuno-histological study ( 170 mouse thyroids: RET/PTC3, E7, wild type, 2- to 10-month-old) with cell cycle proliferation and signalling pathway indicators. The characteristics of both models are different. There is an 'oncogene dependent' cellular signature, maintained at all studied ages in the E7 model, less in the RET/PTC3 model. During tumour development a large heterogeneity occurred in the Tg-RET/PTC3 model within a same tumour or within a same thyroid lobe. The Tg-E7 model was less heterogeneous, with a dominant goitrous pattern. The solid tumour already described in the RET/PTC3 models associated with cribriform patterns, suggested 'PTC spindle cell changes' as in humans PTC rather than the equivalent of the solid human PTC. Proliferation and apoptosis in the two thyroid models are related to the causal oncogene rather than reflect a general tumorigenic process. The thyroids of RET/PTC3 mice appeared as a partial and transient model of human PTCs, whereas the Tg-E7 mice do not belong to the usual PTC type. British Journal of Cancer (2008) 99, I874- | 883. doi:I0.1038/sj.bjc.6604740 www.bjcancer.com Published online 4 November 2008 (c) 2008 Cancer Research UK

Keywords: cribriform patterns in thyroid tumour; RET/PTC3 and E7 transgenic mice; papillary thyroid carcinoma

Thyroid function, growth and differentiation are mainly controlled by two pathways: the TSH-cAMP cascade and the growth factor pathways. The oncogenic stimulations of these pathways initiate different types of tumours (Dumont et al, 1989, 2005; Williams, 1994; Fagin, 2002; Fusco et al, 2002). To experimentally study these diseases, different mouse models have been created.

Rearrangements of the RET tyrosine kinase receptor gene (RET/ PTCs) are found in 2.6-34\% of human papillary thyroid carcinomas (PTC) and are even more prevalent in radiationinduced paediatric PTC (Baverstock et al, 1992; Kasakov et al, 1992). The rearranged RET/PTCs oncogene are activated forms of the RET proto-oncogene (Fusco et al, 2002; Santoro et al, 2002). The thyroid-targeted expression of the human RET/PTC3 oncogene under the control of the bovine thyroglobulin promoter in transgenic mice, induces metastatic solid-type papillary carcinomas considered as analogous to the human solid-type PTC (Powell et al, 1998).

The oncogenic properties of the high-risk human papillomavirus (HPV) type $16 \mathrm{E} 7$ protein are attributed to its interaction with RB1 and related proteins (Münger et al, 1989; Weinberg, 1995; Coulonval et al, 1997). Inactivation of these proteins results in a continuous growth of the thyroid, little affecting its differentiation, function and regulation (Iuliano et al, 2000). There is still a debate on RB1 function in human thyroid tumorigenesis with contra-

*Correspondence: Dr L Jin; E-mail: lingjin@ulb.ac.be

Received II June 2008; revised 24 September 2008; accepted 25 September 2008; published online 4 November 2008 dictory results on its loss or overexpression in papillary and follicular carcinomas vs adenomas (Anwar et al, 2000).

The mice expressing the human original HPV type 16 E7 protein under the control of the thyroglobulin promoter develop differentiated and functionally regulated thyroid goitres, before the occurrence of tumours mimicking human-differentiated follicular and papillary thyroid carcinomas. In these transgenic mice, by 1 month, follicular cells are modified, small, and numerous with an increased nuclear/cytoplasmic ratio (Ledent et al, 1995; Coppée et al, 1996). Tumours appearing, over 1 year, have been compared with human thyroid insular carcinomas (Franc et al, 1998).

The coexpression of RET/PTC 3 and E7 in transgenic mouse models lacks any cooperative effect in the neoplastic transformation of thyroid cells and the E7-induced thyroid phenotype is dominant with respect to the RET/PTC3 one. These results are intriguing and were poorly explained (Portella et al, 2000).

Homologies between the E7 model and several features encountered in human benign and malignant thyroid disease have been little explored. We know much about the pathology of RET/ PTC human tumours but much less about their biological evolution. The meaning of solid patterns in human thyroid tumours are a matter of debate.

We have therefore conducted a parallel study of the evolution of gene expression and pathology in E7 and RET PTC3 mice. The transcriptome study (Burniat et al, 2008) revealed differences of gene expression between E7 and RETPTC3 models and between different phases in the evolution of the tumour. The pathological and immunohistological study presented here, in which thyroid 
function, proliferation, and the two involved signalling pathways were completely tested and they explain the gene expression results. Our results permit to further explore some of the diagnostic enigma in human thyroid pathology.

\section{MATERIALS AND METHODS}

RET/PTC3, E7 transgenic and C57Bl/6 wild-type mice were fed with a normal iodine diet and maintained in the animal facility under $12 \mathrm{~h}$ light $/ 12 \mathrm{~h}$ darkness cycle. Animal studies were approved by the Animal Care Use and Review Committee (Commission d'éthique du Bien-Etre Animal) of the Faculty of Medicine, Université Libre de Bruxelles (project 160N, 20072010) and in compliance with the UKCCCR guidelines on animal use.

Experimental groups consist of E7 mice $(n=87)$, RET/PTC3 mice $(n=53)$ and the C57Bl/6 mice $(n=30)$ served as controls. RET/PTC3 and E7 transgenic mice provided by Dr M Santoro (Napoli) and Dr C Ledent (our Institute) respectively were crossed with wild type $\mathrm{C} 57 \mathrm{Bl} / 6$. Both strain progenies were genotyped by PCR (Burniat et al, 2008).

Genomic DNA was prepared from a piece $(0.5 \mathrm{~cm})$ of tail by a lysis treatment at $55^{\circ} \mathrm{C}$ in TNES $(100 \mathrm{~mm}$ Tris- $\mathrm{HCl} \mathrm{pH} 8 / 200 \mathrm{~mm}$ $\mathrm{NaCl} / 5 \mathrm{~mm}$ EDTA/0.2\% SDS/40 $\mu \mathrm{g}$ proteinase K). Selected regions of the human RET and E7 genes were amplified by the PCR method. The primers used for the amplification were: RET forward, 5'-GGCCAGAGCCCTAAGGAGGGC-3'; RET reverse, 5'-AAGGGATTCAATTGCCATCCA-3'. E7 forward, 5'-CATGCAT GGAGATACACCT-3'; E7 reverse, 5'-GATTATGGTTTCTGAGAACA-3'. Amplified products were visualized on agarose gel as 1500 and $300 \mathrm{bp}$ bands respectively.

The antibodies used to test thyroid function were: anti-Tg polyclonal antibody (Dako, Glostrup, Denmark), anti-Tg-I monoclonal antibody B1 (gift from Dr C Ris-Stalpers), anti-NIS rabbit polyclonal antibody (gift from Dr N Carrasco), cell proliferation and signalling pathways: anti-BrdU monoclonal mouse antibody (Becton Dickinson, Rutherford, NJ, USA), anti-Ki-67 monoclonal rat antibody (clone TEC-3, Dako), anti-Cyclin D1 monoclonal rabbit antibody (SP4, NeoMarkers, Fremont, CA, USA); antiPhospho-p44/42 MAPK Thr202/Tyr204 monoclonal rabbit antibody (20G11, Cell Signalling, Danvers, MA, USA), anti-PhosphoAkt Ser473 monoclonal rabbit monoclonal antibody (736E11, Cell Signaling). Primary antibodies, dilution and incubation time are listed in Table 1.

\section{Immunohistochemistry, radioiodide uptake, and proliferation index determination}

The transgenic and control mice were killed at 2, 6 and 10 months of age and thyroids were removed for pathological examination. One or both lobes were fixed in $4 \%$ paraformaldehyde and embedded in paraffin by standard procedures.
For determination of radioiodide uptake, mice were injected intraperitoneally (i.p.) with $0.5 \mathrm{mCi} \mathrm{kg}^{-1}$ body weight $\mathrm{Na}^{125} \mathrm{I}$ (IMS 30; PerkinElmer Life and Analytical Sciences, Boston, MA, USA) in physiological serum. Twenty-four hours after ${ }^{125} \mathrm{I}$ injection, they were perfused with $0.9 \% \mathrm{NaCl}$ during $15 \mathrm{~min}$ before killing. After deparaffinisation and rehydratation, the slides were dipped two times in $42^{\circ} \mathrm{C}$ NTB3 Emulsion (Kodak), stored in light tight box at $4^{\circ} \mathrm{C}$ for 8 days, developed with Kodak D-19 Developer and stained with haematoxylin-eosin (H\&E).

For determination of the proliferation index, 5-Bromo- $2^{\prime}$ deoxyuridine (BrdU, Sigma, Saint Louis, MO, USA) $0.5 \mathrm{mgg}^{-1}$ body weight was injected i.p. $24 \mathrm{~h}$ before killing. The thyroids were fixed in Clarke's fixative (75\% V/V ethanol: $25 \% \mathrm{~V} / \mathrm{V}$ glacial acetic acid) $18 \mathrm{~h}$ after perfusion of the mice, embedded in paraffin. BrdU was detected by immunohistochemistry. DNA in the samples was denatured in two $\mathrm{N} \mathrm{HCl}$, followed by neutralization in $0.1 \mathrm{M}$ borate buffer, $\mathrm{pH} 8.5$.

For immunohistochemical analysis of protein expression, the endogenous peroxidase activity was quenched by a treatment with $6 \% \mathrm{H}_{2} \mathrm{O}_{2}$ in absolute methanol; non-specific-binding sites were blocked with $10 \%$ normal goat serum for Tg and Tg-I, normal horse serum for others. After incubation with primary antibodies, tissue sections were sequentially incubated with second antibodies conjugated to peroxidase-labelled polymer (EnVision detection, Dako) for Tg and Tg-I or goat biotinylated secondary antibodies (Jackson ImmunoResearch, West Grove, PA, USA) (Table 1) and Avidin-conjugated horseradish peroxidase ABC system (Dako) for others. Staining was developed with aminoethylcarbazole-AEC (Dako) and diaminobenzidine-DAB (Dako) substrates (Table 1) and sections were slightly counterstained with Mayer's haematoxylin. Negative controls were performed using a replacement of the first antibodies with a blocking solution.

The BrdU, Ki-67, and Cyclin D1 labelling index values were evaluated by counting the number of immunopositive cells out of a total of thousand cells (Mean \pm s.e.m.). At least two different slides from the same mouse thyroid were counted.

\section{RESULTS}

The thyroids of all the mice used presented a similar level of E7 or RET/PTC mRNA transgene expression by RT - PCR (not shown). When compared with the wild type (WT) taken as control, RET/ PTC3 and Tg-E7 transgenic mice thyroid harboured two different phenotypes. According to age, the Tg-E7 model evolved on a predominant goitrous mode with no tumour formation, whereas tumour formation occurred in $28 \%$ of the RET/PTC 3 mice at 6 and 10 months. A hyperplastic background occurred in both models with peculiar characteristics in the RET/PTC3 model.

The dominant feature at the cellular level was the occurrence of 'oncogene-dependent' follicular cell changes, leading to different cellular phenotypes, small cells in the E7 model and large cells in the RET/PTC3 model, which evolved differently with time.

Table I Detection of thyroid-specific, cell cycle and cell pathway proteins

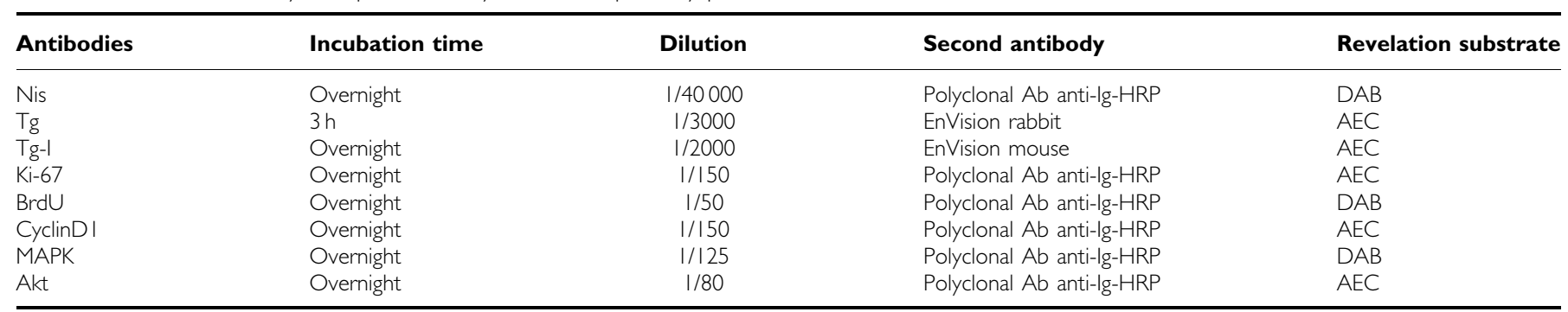

$\mathrm{AEC}=3$-amino-9-ethylcarbazole; $\mathrm{DAB}=3,3^{\prime}$-Diaminobenzidine tetrahydrochloride. 
In the E7 model these cellular changes were not reminiscent of the human PTC cells, which are also different from the RET/PTC3 model.

Those histological findings were accompanied by changes in the expression of proteins related to thyroid function, proliferation indices, PKB and MAPkinase pathways.

Our results represent a precise histological description of the follicular cell changes, hyperplastic and tumour features, followed by corresponding data concerning thyroid function, cell proliferation, PKB and MAPkinase pathway indicators. The several encountered modifications occurring in the transgenic models in comparison with controls are described according to age.

\section{Follicular cell changes}

At 2 months, WT mouse thyroids harboured cuboidal follicular cells lining small follicles (Figures $1 \mathrm{~A}-\mathrm{C}$ and $2 \mathrm{~A}$ ). The size of the follicles became heterogeneous at 6 months, with dominant large follicles lined by flat cells at 10 months (Figure 2B and C).

E7 thyroids were much larger than WT thyroids at all ages (Figure 1D-F). At 2, 6, and 10 months, the follicular cells, with a not well marked cellular border, were crowded and overlapping all around the follicles, with a 1.9-fold cell number increase at 2 months in comparison with the WT (Figure 2A and D). The nuclei were hyperchromatic with an increase in the nuclear/cytoplasmic ratio (Figure 2D), The follicular border appeared 'palissade like' (Figure 2D-F). At 6 and 10 months huge follicles lined with flat follicular cells (Figures 2E, F, 3B and Q) coexisted with small round and irregularly shaped follicles with 'palissade like' borders (Figures 2E, F, 3B and Q).

RET/PTC3 thyroids were larger than control thyroids at all ages but smaller than those of the E7 model (Figure 1). The modifications were different from one mouse to another.

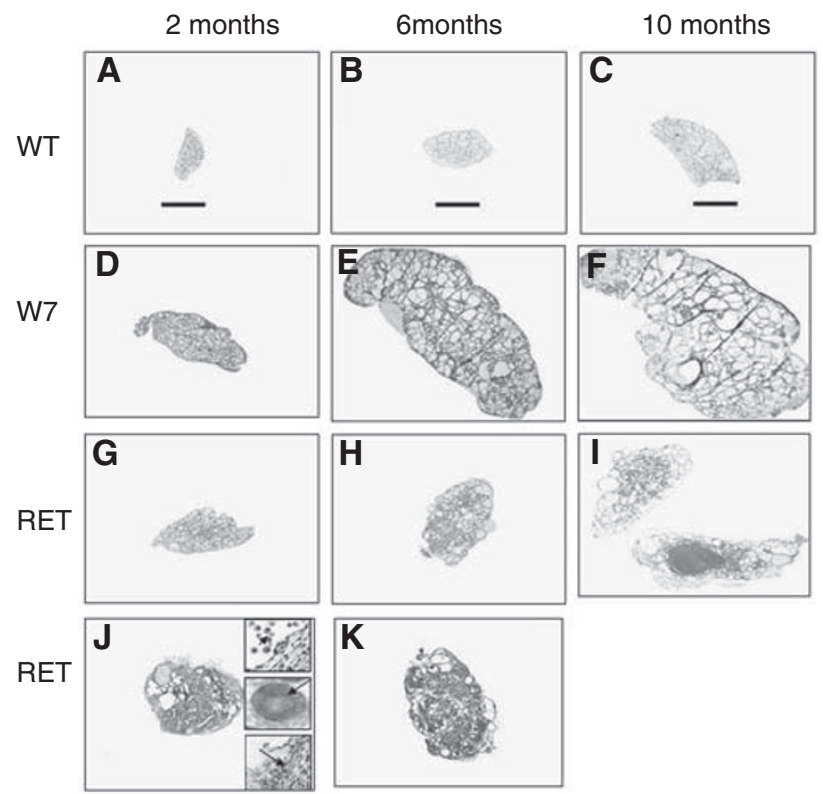

Figure I Paraformaldehyde-fixed, paraffin-embedded and haematoxylin-eosin stained thyroid tissues from C57BI/6, E7 and RET/PTC3. (A-C) 2, 6, and 10-month C57BI/6 thyroids respectively; (D-F) 2-, 6-, 10-month E7 thyroids respectively; (G-I) 2-, 6-, 10-month RET/PTC3 respectively, (I) two lobes from the same mouse; (J and K) 2-, and 6-month RET/PTC3 with remodeling and cyst (diffuse sclerosing); upper right insert of $\mathbf{J}$ : macrophages infiltration, middle right insert of $\mathbf{J}$ : nuclear inclusion; low right insert of J: thick spindle-like cells in between follicles. Original magnification $2.5 \times$. Scale bar: I $\mathrm{mm}$.
At 2 months, part of the cells were modified; they were larger (more than $8 \mu \mathrm{m}$ instead of $3 \mu \mathrm{m}$ ), lining all or part of the thyroid follicles, stratified in some areas (Figure 2G). The cytoplasm was large with a convex apical border and a decreased nuclear/ cytoplasmic ratio, a pale nucleus, sometimes pleomorphic with dispersed chromatin (Figure 2G). The nucleus location and polarity were disturbed (Figure 2G). At 6 and 10 months, many follicular cells were still large but some were not (Figure $2 \mathrm{H}$ and $\mathrm{I}$ ).

\section{Hyperplastic features}

Absent in the WT, hyperplastic areas were present in both E7 and RET/PTC 3 as micro or larger papillary infoldings with or without secondary follicles. Present already in the 2-month models, these papillae became more numerous with age, especially in the E7 model with a branching distribution, often situated in the centre of the lobe inside dilated follicles (Figure 2D-F). In the RET/PTC3 model, the thyroid organisation was progressively replaced at 6 and 10 months, in $20 \%$ of the examined thyroids, by a cribriform pattern difficult to distinguish in some cases from a true diffuse tumour process (Figure $2 \mathrm{H} 2$ ). The cell changes already described persisted in the two models at 6 and 10 months.

In $28 \%$ of the examined RET/PTC3 thyroids a peculiar pattern emerged at 2 months. Thyroid lobes were totally replaced by a series of large cysts filled with papillary structures more or less coalescent, bordered with large cells, with rare nuclear cytoplasmic pseudo inclusion (Figure 1J middle insert) and pleomorphism. Peripheral cysts were filled with macrophages (Figure 1J). A mixture of true mesenchymatous tissue and sheets of spindle or more round cells, in close vicinity with the wall of the cyst or their papillary content, existed between cysts (Figures 1J and 2G2). In the absence of a true definition of this pattern in the literature, we identify them as 'proliferative papillary cystic changes with spindle cells and remodeling'. They were rare at 6 months and absent at 10 months.

Peripheral large cysts with a discrete micropapillary border in an otherwise 'normal' or moderately hyperplastic thyroid structures were encountered in 45 and $58 \%$ of the 6 and 10 months thyroid RET/PTC 3 models respectively (Figures 2H1, 3D, I, N and $S)$.

\section{Distinct tumours}

They were absent in the WT and we did not find any in the E7 model. In the RET/PTC3 mice, true tumours were already visible in $16 \%$ of the cases, either at 6 months and most often at 10 months (Figure 1I). These tumours (small foci around $1 \mathrm{~mm}$ or macroscopically visible $5 \mathrm{~mm}$ diameter tumour) were unique or multiple. They were not or only partially circumscribed. The dominant histological pattern was solid without an obvious follicular or papillary structure. Cells harboured either a large cytoplasm (Figure 2I) and oval nucleus or were spindle-like with less cytoplasm (Figure 2I). Some mitoses were observed. The two thyroid lobes of the same mouse could show different lesions, mostly associated with the 'cribriform pattern' (Figures 1I and $2 \mathrm{H} 2)$.

\section{Thyroid function}

WT mice At all ages Tg staining was observed in the follicular lumen (Figure 3F). Radioiodine incorporation (Figure 3P) paralleled the immunostaining of Tg-I (Figure 3K). At 2 months the follicles presented a high capability to bind radioiodide, which decreased and disappeared in the follicles lined with flat cells at 6 and 10 months (Figure $3 \mathrm{~K}$ and P). NIS was detected in a basolateral position of the follicular cells at 2 months (not shown). This uniformity decreased with age and NIS was absent in the flat cells (Figure 3A). 

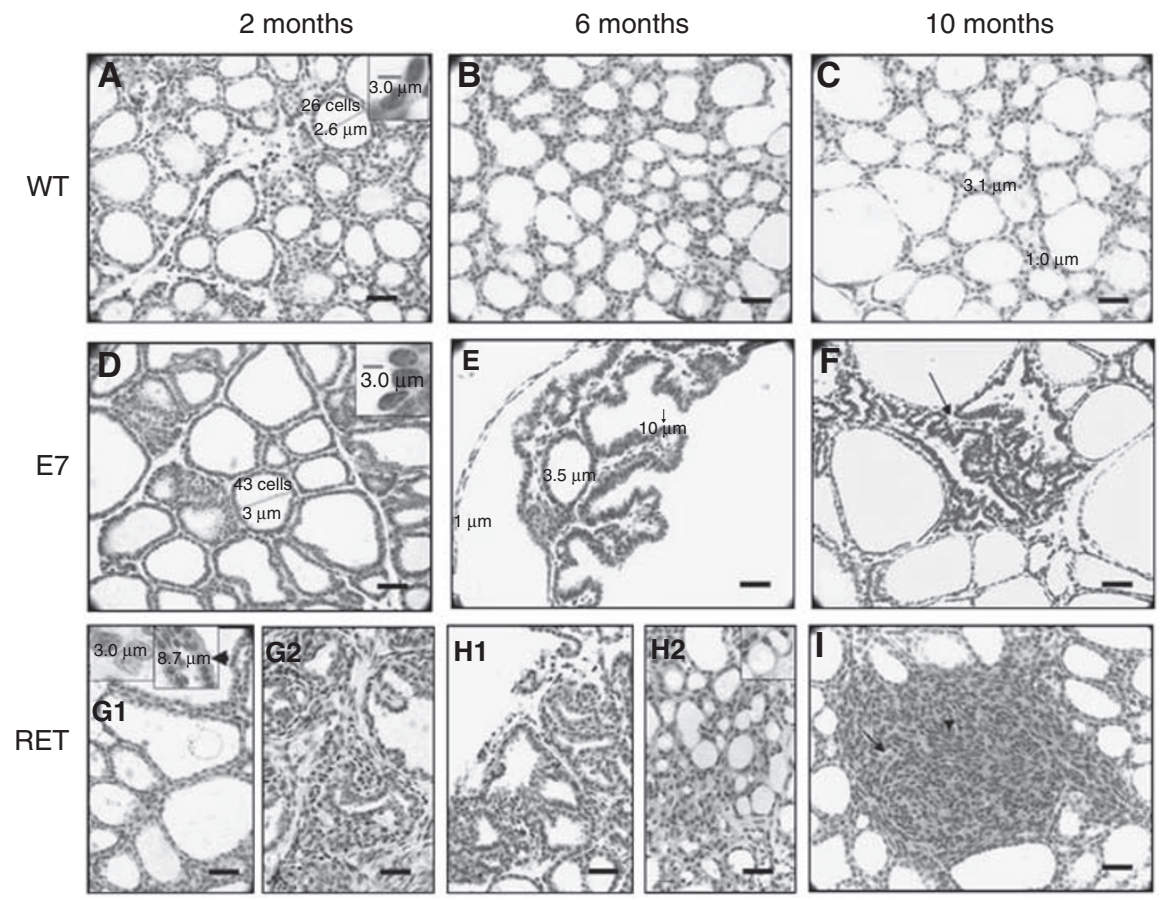

Figure 2 Haematoxylin-eosin stained C57BI/6, E7 and RET/PTC3 thyroid glands. (A-C) wild type C57BI/6 thyroids; (D-F) E7 thyroids; (G-I) RET/ PTC3 thyroids. Upper right inserts in A: WT nuclei, in B: E7 nuclei and upper left insert in G I: pale, pleomorphic with dispersed chromatin nuclei and nuclear groove, red scale bar: $3 \mu \mathrm{m}(\mathrm{I} 00 \times)$, upper right insert in $\mathbf{G ~ I}$ : large thyrocytes with a decreased ratio of nuclear/cytoplasm (0.27-0.55) compared with WT (1.20) and E7 (3.97-22.67) thyrocytes, red bar equal to $8.7 \mu \mathrm{m}$ (40 × ); (G2) 2-month RET/PTC3 with remodeling and cyst (diffuse sclerosing); (HI) disorganised papillary cyst zone in 6-month RET/PTC3 thyroid. (H2) cribriform structures in RET/PTC3; upper insert: two small follicles share one part of the follicular 'wall'; (I) solid tumour structure in RET/PTC3, long arrow: cells harboured a large cytoplasm and oval nucleus, short arrow: spindle-like with less cytoplasm. Original magnification $\times 40$ for $\mathbf{A}-\mathbf{I}$; scale bar: $30 \mu \mathrm{m}$.

E7 mice At all ages $\mathrm{Tg}$ staining was observed in the follicles (Figure $3 \mathrm{G}$ ). Half of the follicles were labelled at 2 months for Tg-I but the corresponding staining decreased at 6 and 10 months (Figure $3 \mathrm{~L}$ and $\mathrm{Q}$ ). Tg-I persisted in the small round and irregular shaped follicles and in the follicles close to the papillary infoldings (Figure 3L). Autoradiography confirmed the limited localisation of Tg-I (Figure 3Q). NIS was detected in the majority of thyroid epithelial cells at 2 months and in the Tg-I-positive areas at 6 and 10 months. It disappeared in the flat cells (Figure 3B).

RET/PTC3 mice At 2 months, NIS was expressed only in the large cells. The number of follicles positively labelled for Tg-I and displaying radioiodine was systematically lower than in E7 and WT mice. Tg was observed in all follicles. By 6 months and later, low cuboidal-flat follicular cells displayed a rare expression of NIS, no radioactive iodide incorporation (Figure $3 \mathrm{C}$ and $\mathrm{R}$ ) and no $\mathrm{Tg}-\mathrm{I}$ immunostaining (Figure $3 \mathrm{M}$ ) whereas $\mathrm{Tg}$ was still present (Figure $3 \mathrm{H}$ ). In the disorganised papillary regions at the periphery of the gland, the modified follicular cells expressed NIS in a basolateral position (Figure 3D). The lumen was devoid of iodide uptake and Tg-I labelling. Tg only persisted as a lining at the apical border of the follicular cells (Figure 3I, N and S).

In the solid tumour, NIS and Tg were situated in the cytoplasm of the cells. The intensity of the staining varied from one region to the other (Figure $3 \mathrm{E}$ and J). Tg-I was negative (Figure 3O).

\section{Thyroid tumour growth}

Measurements of Ki-67 and BrdU-labelling indexes showed the same features. In WT, RET/PTC3, and E7 thyroids the overall proliferation index was the highest at 2 months and decreased with age. Compared with WT, the frequency of positive proliferation indexes was systematically higher in both thyroid models and higher in E7 than in RET/PTC3 at all ages (Table 2). In 2-monthold E7 thyroids, the number of proliferating cells was increased compared with WT (Table 3, Figure 4C and O) and homogenously distributed. At 6 and 10 months, proliferating foci were mainly located in small irregularly shaped follicles and papillae. Proliferation was very rare in flat cells (Table 3 , Figure $4 \mathrm{D}$ and $\mathrm{P}$ ).

In RET/PTC3 thyroids proliferating foci were often located in the papillary infoldings and in the solid tumour (Table 3, Figure 4F). Cyclin D1 immunolabelling paralleled the results obtained with BrdU and Ki-67 (Table 3, Figure 4K and L).

In the E7 model, Cyclin D1 immunolabelling was very low in follicular cells compared with WT, but was positive in the nucleus of a great number of stromal cells. It was rarely positive in control stroma (Table 3, Figure 4I and J). Some human thyroid nodular goitre and differentiated thyroid carcinoma presenting morphology and nuclear features (Figure 5A and C) similar to E7 mouse model also showed stromal cell-positive staining for Cyclin D1 (Figure 5B and D). In mouse E7 model, no apoptosis, as measured by Tunel assay and by immunohistochemical detection of activated caspase 3, could be observed in thyrocytes of both transgenic models and wild-type mice (not shown).

\section{The PKB and MAP kinase pathways}

At 2 months, phosphorylated $\mathrm{PKB} / \mathrm{Akt}$ expression was cytoplasmic, slightly weaker in E7 (Figure $6 \mathrm{C}$ and D) than in RET/PTC3 (Figure 6E and F) and WT mice (Figure 56A and B). Staining decreased at 6 months in WT thyroid, but was unchanged in RET/ PTC3 follicular cells (visible in some nuclei) (Figure 6B and F).

In WT thyroids phosphorylated MAPK showed a nucleocytoplasmic staining that almost disappeared at 6 months (Figure $6 \mathrm{G}$ and $\mathrm{H}$ ). In RET/PTC3 MAPK staining was stronger and 


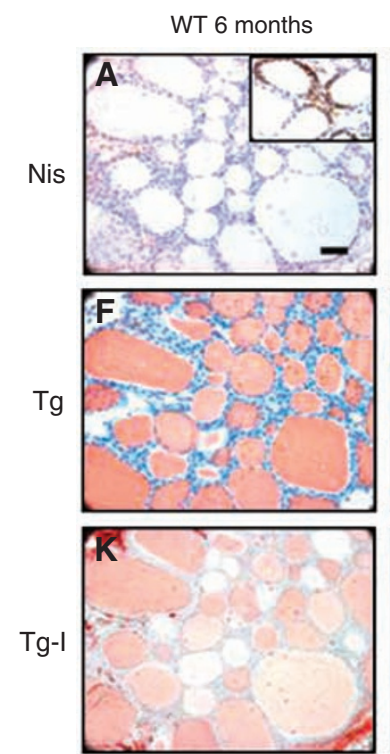

E7 6 months
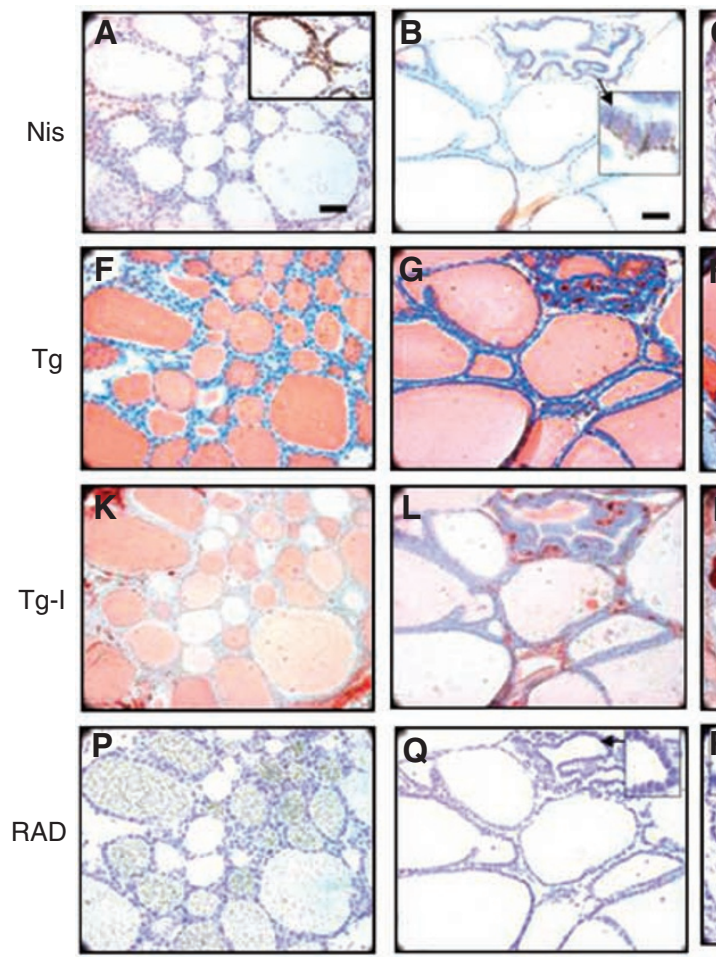

RET/PTC 6 months
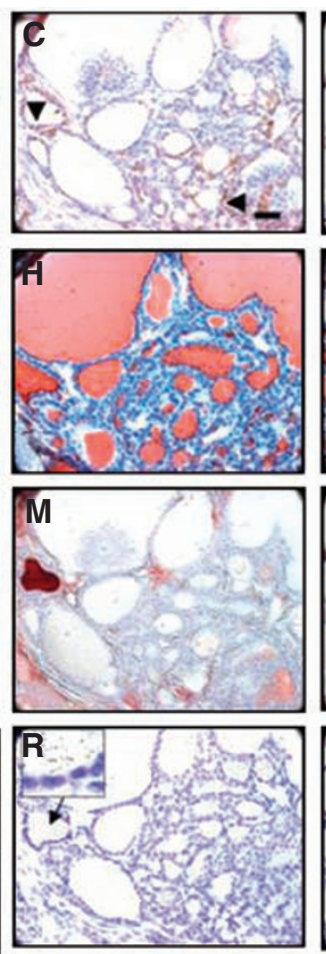

RET/PTC 6 months
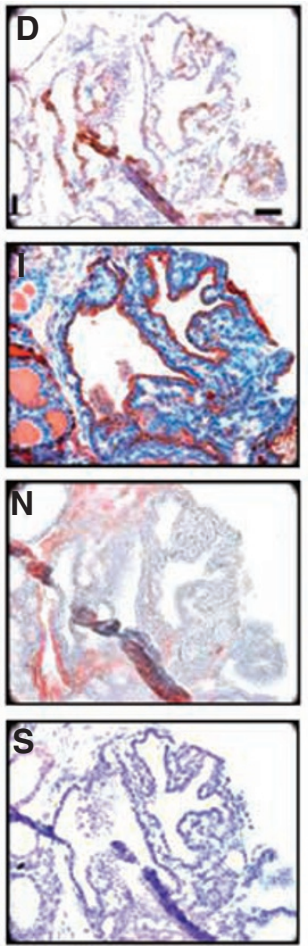

RET/PTC 10 months (solid)
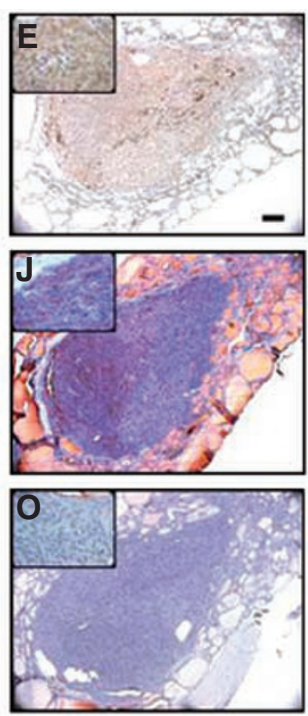

Figure 3 Immunohistochemistry for Sodium lodide Symporter (NIS), Thyroglobulin (Tg), lodinated-thyroglobulin (Tg-I) and incorporation of iodide visualized by autoradiography (ARG). (A, F, K and $\mathbf{P}$ ) 6-month C57BI/6, NIS, Tg, Tg-I immunostaining and autoradiography, respectively; (B, G, L and $\mathbf{Q}$ ) 6-month E7, NIS, Tg, Tg-I immunostaining and autoradiography, respectively; (C, H, M and R) 6-month RET/PTC3, NIS, Tg, Tg-I immunostaining and autoradiography, respectively; (D, L, N and S) 6-month RET/PTC3, disorganized papillary cyst region NIS, Tg, Tg-I immunostaining and autoradiography respectively; (E, J and $\mathbf{O}$ ) I 0-month RET/PTC3, solid mass region NIS, Tg, Tg-I immunostaining, respectively. Original magnification for $(\mathbf{E}, \mathbf{J}$ and $\mathbf{O}): \times$ I0, scale bar: $100 \mu \mathrm{m}$. Original magnification for other images: $\times$ 40; scale bar:30 $\mu \mathrm{m}$. Inserts magnification: $\times 40$.

Table 2 General table of dominant patterns in RET/PTC3 thyroids

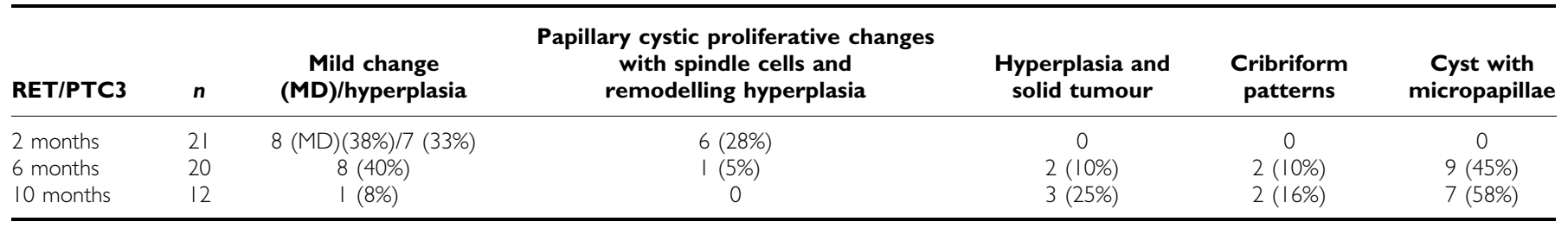

predominantly located in the nucleus. It was maintained at 6 months (Figure $6 \mathrm{~K}$ and $\mathrm{L}$ ). On the contrary, only a weak labelling was found in the cytoplasm of E7 epithelial cells with the 'palissade like' appearance and sometimes in their nucleus (Figure 6I and J).

\section{DISCUSSION}

As in previous studies on transgenic E7, and RET/PTC3 mouse models (Ledent et al, 1995; Coppée et al, 1996; Powell et al, 1998; Portella et al, 2000) the generally encountered features such as hyperplasia, and solid tumours in the RET/PTC3 model are present. The cellular modification and the goitre present in the E7 model were as already described. However, we do not find tumours in the E7 model, but our study ended earlier (10 months) than the other studies. We do not find in the literature any precise description of the cellular modification encountered in the RET/PTC3 model, nor fully documented data on the several tested parameters we presented (thyroid function, proliferative indices, pathway indicators). Some studies tested thyroid function, as serum thyroid hormone level, or tissue thyroglobulin expression (Ledent et al, 1995). Few of the tested cell cycle indicators presented in our study have been tested. Moreover our findings on cyclin D1 expression in an E7 model have never been previously mentioned. In both models the PKB and MAPkinase pathways were not analysed. However, the low rate of tumour formation encountered in our study of the E7 or RET/PTC3 models differed from previous studies. In our E7 model, at 10 months, we do not find tumours, whereas a $15 \%$ occurrence of carcinomas at 12 months was observed in the E7 model (Portella et al, 2000). In the RET/PTC3 model, Portella et al (2000) described $42 \%$ of tumours at 12 months, Powell et al (1998), 55\% at 6 months.

To explain such discrepancies, we can exclude a loss of expression of the transgene. Its expression was constant from one animal to the other and did not vary with age. Nevertheless, within one thyroid, one could not assert a uniformity of expression of the transgene all over the thyroid. The homology of the studied strains in the different literature series must be discussed. A long time duration exists between the generation of the two transgenic 
Table 3 Proliferation index in E7 and RET/PTC3 thyroid cell

$E 7(n=83)$

\begin{tabular}{|c|c|c|c|c|}
\hline Age of mice & 2 months $(n=26)$ & $6 / 10$ & months $(n=57)$ & \\
\hline Pathological changes & Hyperplasia & $\begin{array}{c}\text { Papillae and small } \\
\text { irregular follicles "palisade } \\
\text { like" border }\end{array}$ & $\begin{array}{c}\text { Follicles cuboidal } \\
\text { cell }\end{array}$ & Large follicles: flat cell \\
\hline $\begin{array}{l}\text { Height of follicular } \\
\text { cells }(\mu \mathrm{m})\end{array}$ & $3.0 \mu \mathrm{m}$ & $10.0 \mu \mathrm{m}$ & $3.0 \mu \mathrm{m}$ & $1.0 \mu \mathrm{m}$ \\
\hline
\end{tabular}

\begin{tabular}{|c|c|c|c|c|}
\hline \multicolumn{5}{|l|}{ Cell cycle markers } \\
\hline $\begin{array}{l}\text { Ki-67 } \\
\text { Cyclin DI }\end{array}$ & $368.19 \%$ (WT 17.27\%0) & $317.70 \%$ (WT 8.26\%) & 67.20\% (WT 8.26\%o) & 8.20\%o (WT 8.26\%o) \\
\hline Thyrocytes & $0.143 \%$ (WT I I.1\%o) & & $0.275 \%$ (WT $2.25 \%$ ) & \\
\hline $\begin{array}{l}\text { Stromal cells } \\
\text { BrdU }\end{array}$ & $\begin{array}{c}21.81 \% 0 \\
44 \% \text { (WT 3.7\% })\end{array}$ & $\begin{array}{c}33.79 \% \\
\mid 4.23 \% 0 \text { (WT 0.4\%o) }\end{array}$ & $\begin{array}{c}10.55 \% \\
5.29 \% \text { (WT } 0.4 \% \text { ) }\end{array}$ & $\begin{array}{c}3.87 \% 0 \\
0.43 \% \text { (WT } 0.4 \% \text { ) }\end{array}$ \\
\hline
\end{tabular}

RET/PTC3 $(n=53)$

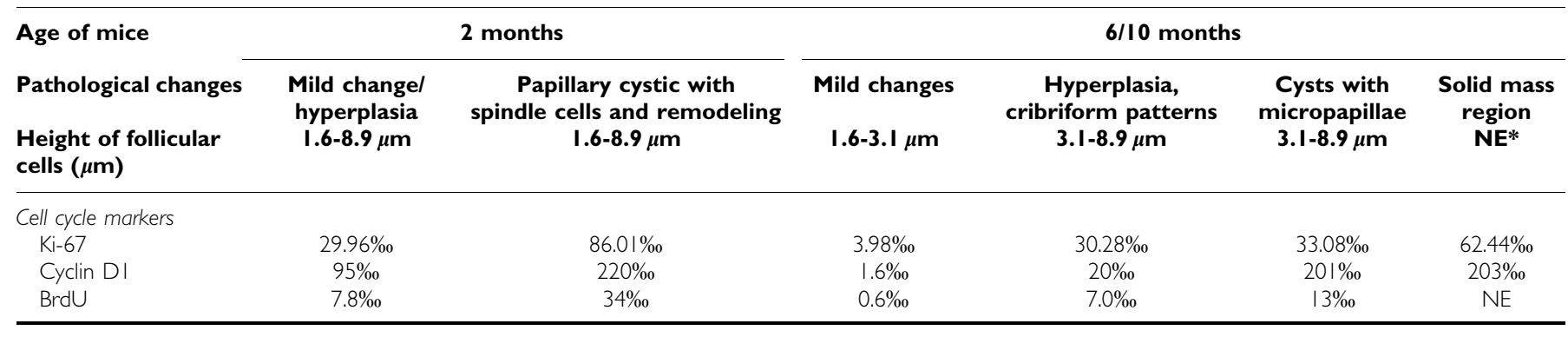

$\mathrm{NE}=$ not examined. NE* the heterogeneity of the cellular component (size and shapes) does not permit any measurement. The proportion of epithelial cells labeled was estimated as per thousand (\%) of the total number of thyrocytes, and presented as mean values \pm s.e.m. For scoring, at least a thousand thyrocytes on two different slides were counted in one mouse thyroid.

Ki-67 2 months

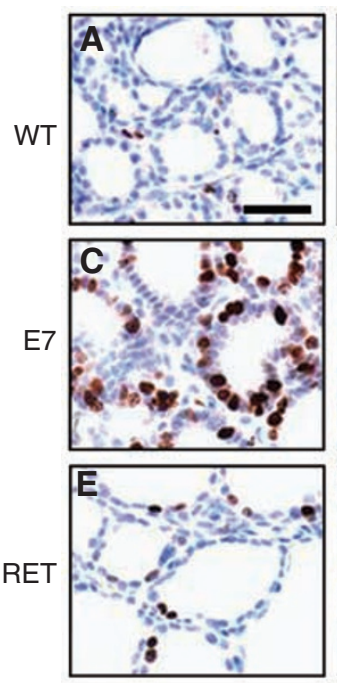

Ki-67 6 months
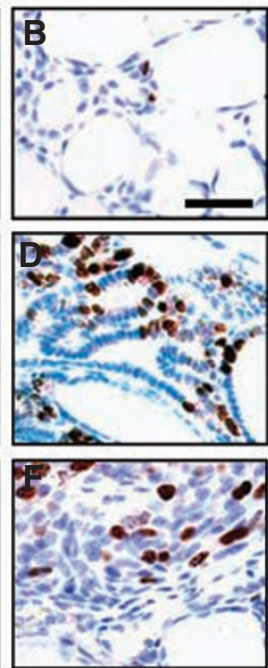

Cyclin D1 2 months Cyclin D1 2 months
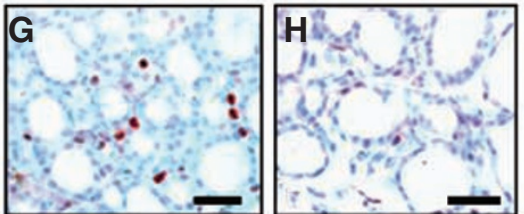

BrdU 2 months

BrdU 6 months
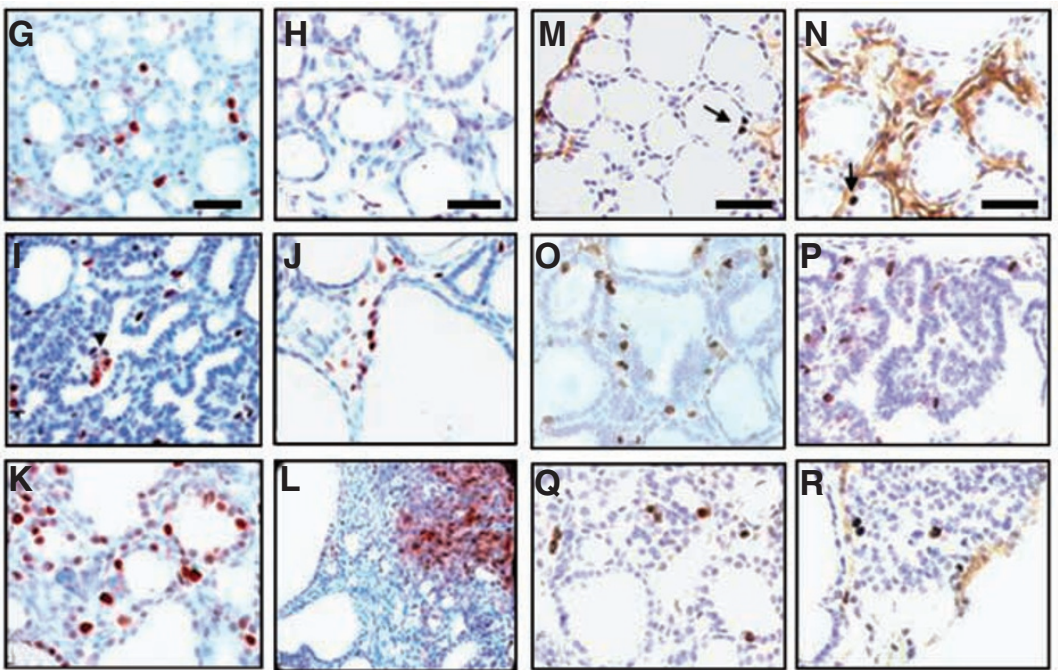

Figure 4 Immunohistochemistry for Ki-67 (A-F), Cyclin DI (G-L) and BrdU stainings (M-R) in thyroid tissues from C57BI/6, E7 and RET/PTC3. (A, G and M) 2-month C57BI/6; (B, H and $\mathbf{N}$ ) 6-month C57BI/6; (C, I and O) 2 month E7; (D, J and $\mathbf{P})$ 6-month E7; (E, K and $\mathbf{Q})$ 2-month RET/PTC3; (F, L and R) 6-month RET/PTC3. Upper left part of (F) and upper right corner of (L): solid mass regions. (R): disorganized papillary tumour region. Original magnification: $\times 40$; scale bar: $30 \mu \mathrm{m}$.

mice models and our study. Moreover the initial hybrid background present in both models, had declined with time due to a backcross in our study with a C57Bl/6 wild type. This can probably explain part of the differences with older series. This backcross should represent a good opportunity to identify modifier genes in the C57B1/6 genetic background responsible for the phenotype changes. In addition, we cannot exclude terminological differences as part of our discrepancies.

Our extensive study raises several points:

- the association in both models of peculiar cellular dysplastic changes and hyperplasia which could be called 'dysplastic hyperplasia'. 

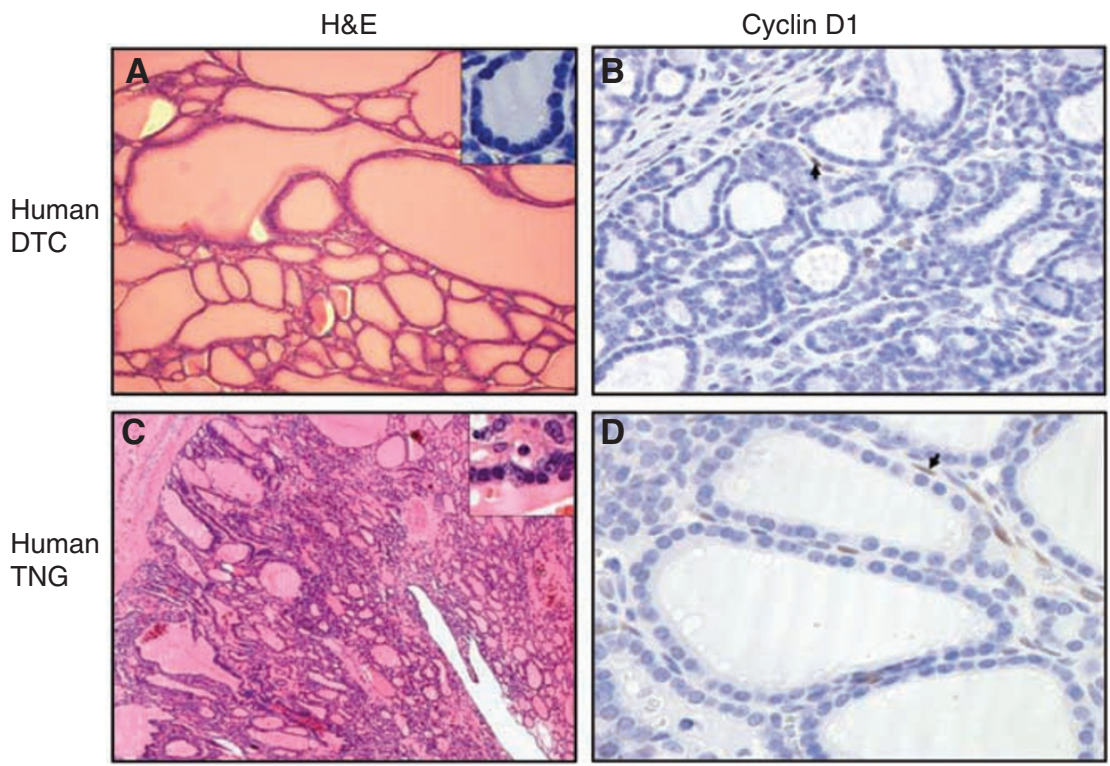

Figure 5 Haematoxylin-eosin and Cyclin DI immunohistochemistry stainings of $\mathbf{A}$ and $\mathbf{B}$ : human differentiated thyroid carcinoma; (C and $\mathbf{D})$ Human thyroid nodular goitre. Upper right inserts in $\mathbf{A}$ and $\mathbf{C}$ : small thyrocytes with high nuclear/cytoplasm ratio. Arrows in $\mathbf{B}$ and $\mathbf{D}$ : positive stromal cell nuclei for Cyclin DI. Original magnification: $\times 20$ for $\mathbf{A} ; \times 60$ for $\mathbf{B} ; \times 4$ for $\mathbf{C}$ and $\times 40$ for $\mathbf{D}$.
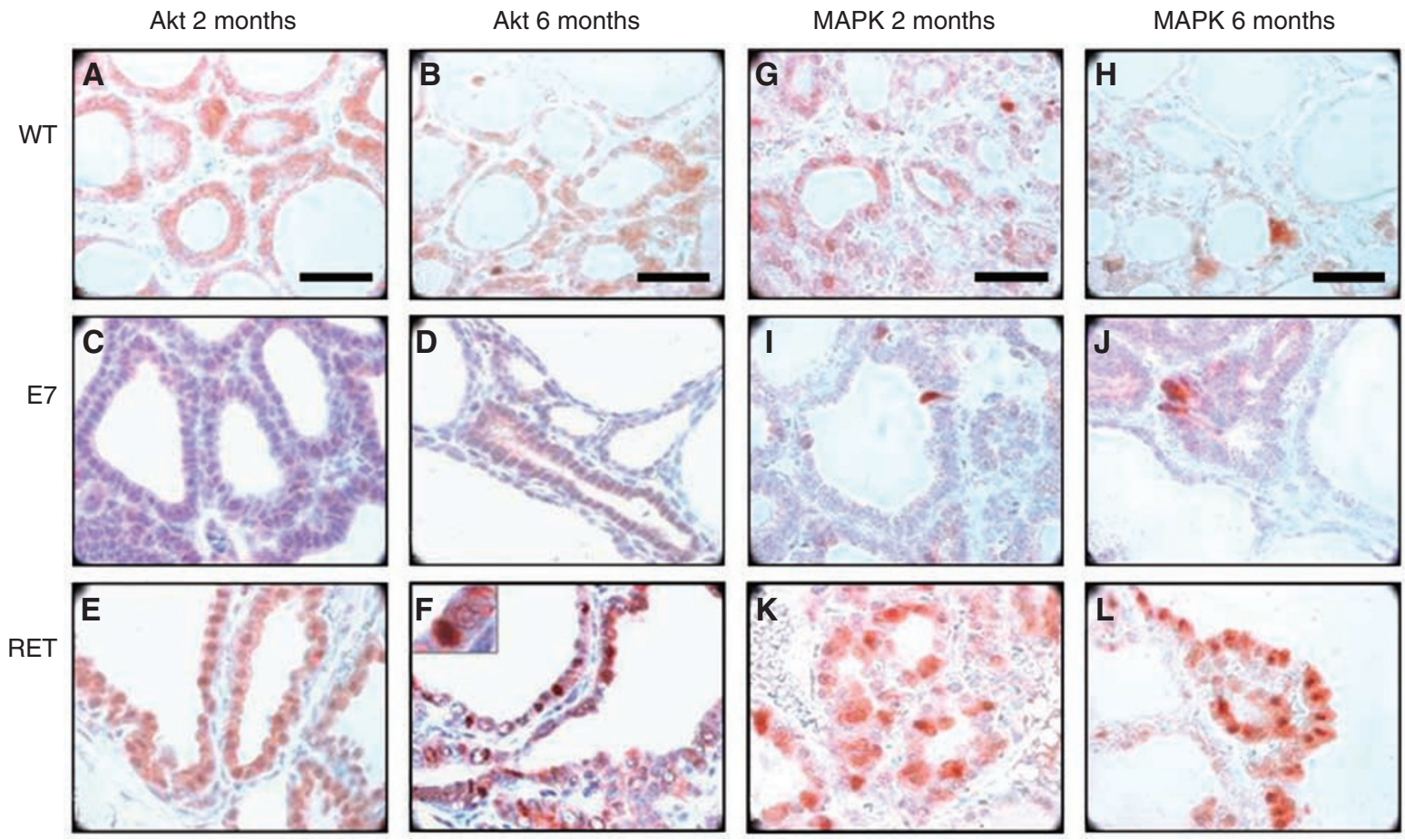

Figure 6 Immunohistochemistry for p-PKB/Akt $(\mathbf{A}-\mathbf{F})$ and p-MAPK $(\mathbf{G}-\mathbf{L})$ in thyroid tissues from C57BI/6, E7 and RET/PTC3. (A and $\mathbf{G}) 2$-month C57BI/6; (B and H) 6-month C57BI/6; (C and I) 2-month E7; (D and J) 6-months E7; (E and K) 2-month RET/PTC3; (F and L) 6-month RET/PTC3. Original magnification: $\times 100$; scale bar: $30 \mu \mathrm{m}$.

- the heterogeneity we describe in our RET/PTC3 model with the cribriform patterns and the 'proliferative papillary cystic changes with spindle cells and remodeling' is not mentioned by others. However, the picture obtained in our study corresponds to some of the descriptions by Powell et al (1998); Powell et al (1998) define PTC 'as cellular nodules adjacent to, or extending into colloid filled follicles'; Russell et al (2000) define carcinoma as: 'more than 50 thyroid follicular epithelial cells clustered together with a homogeneous appearance. Epithelial cell clusters may form a continuous sheet or papillae that surround a fibro-vascular stalk. The nucleus may be either homogeneous or pleiomorphic'. No precisions are added considering whether or not those cell proliferations are inside a follicle. In human pathology, a diagnosis of thyroid carcinoma would not be accepted on such criteria, for example when the proliferation is included in a follicle, even if distended. 
A similar confusion arises when the solid-type papillary carcinoma occurring in RET/PTC 3 transgenic mice is considered as an equivalent of the solid PTC variant found in radiationinduced thyroid cancer of children harbouring an RET/PTC3 rearrangement (Powell et al, 1998; Thomas et al, 1999). The encountered mouse features are very far from the solid human variant in which the tumour cells with PTC nuclear features are still round, organised in sheets or trabeculae of variable size, with a tendency to keep follicular patterns, even rudimentary.

The solid pattern described in transgenic mice is not specifically induced by RET/PTC3 oncogene. Several transgenic mouse models, either RET/PTC1 (Jhiang et al, 1996), RET/PTC3 (Powell et al, 1998; Portella et al, 2000), TRK-T1 (less often) (Russell et al, 2000), A2aR/E7 (Coppée et al, 1996) and so on, develop solid tumours. Certain conditions favoured the occurrence of a solid phenotype: TSH stimulation of RET/PTC1 model (Sagartz et al, 1997), double transgenic mice RET/PTC3 P53-/53- (La Perle et al, 2000; Powell et al, 2001). Other conditions prevent it such as the double transgenic model RET/PTC3-E7 (Portella et al, 2000).

The RET rearrangement, either RET/PTC1 or RET/PTC3, looks as a facilitator in the development of spindle cells in transgenic mice at early stage (Cho et al, 1999), or later on (Williams, 1994; Sagartz et al, 1997). The association with a cribriform pattern is also mentioned in the RET/PTC1 mouse model (Jhiang et al, 1996). Pictures from RET/PTC3 and RET/PTC1 solid variants show some differences; large proliferative spindle cell areas with less visible cytoplasm are more developed in the RET/PTC3 model (Sagartz et al, 1997; Powell et al, 1998).

In the human series of Nikiforov et al (1997), RET/PTC3 tumours are solid, PTC classical, follicular, or a diffuse sclerosing variant. In the adult series of Basolo et al (2002), one-third is tall cell PTC, as in part of the Nakazawa et al (2005) PTC series. We cannot precisely determine whether or not our solid mouse tumour corresponds to a PTC with a spindle-cell metaplasia as described in human PTC (Vergilio et al, 2002) or to a progressive transformation in a less differentiated phenotype (Bronner and LiVolsi, 1991; Brandwein-Gensler et al, 2004). Favouring this last hypothesis, the morphology of these solid tumours is heterogeneous, unlike the homogeneous description mentioned in early literature (Powell et al, 1998). Indeed in these areas one observes a modified NIS, Tg, and TTF-1 immunolabelling and high proliferation indices, as in human aggressive tumours.

The association of cribriform tumour patterns and spindle cells is described in the columnar human PTC (Wenig et al, 1998) without any knowledge of the RET/PTC3 status, and in the morular/cribriform PTC (Harach et al, 1994; Cetta et al, 1999). This last entity, sporadic or associated with the Familial Adenomatous Polyposis syndrome, has been studied at the molecular level, which revealed an APC germline mutation associated with somatic RET/PTC3 oncogene rearrangement (Soravia et al, 1999).

'The proliferative papillary cystic changes with spindle cells and remodeling pattern', which emerged at a quite early age of 2 months in our RET/PTC3 model is puzzling. The number of such phenotypes decreased at 6 months and totally disappeared at 10 months. We wonder whether it may correspond to the rare human young age 'diffused sclerosing' variant (Chow et al, 2003), with its mesenchymal remodeling and inflammatory background, or as found by Russell et al (2004) in the RET/PTC3 mouse in the strain background $\mathrm{C} 57 \mathrm{BL} / 6$.

In both RET/PTC3 and E7 transgenic mouse thyroids, the ability to concentrate radioiodide is generally reduced as in human thyroid carcinomas (Gérard et al, 2003).

In the disorganised papillary cystic regions of the RET/PTC3 model, NIS is overexpressed, but not Tg-I, and there is no iodide uptake. This can be correlated with data in the human PTC. It could be due to an increased intracellular NIS misexpression
(Saito et al, 1998; Wapnir et al, 2003; Riesco-Eizaguirre and Santisteban, 2006), to conformational changes (Gérard et al, 2003) or to the non maturation of hNIS (Trouttet-Masson et al, 2004).

RET stimulates MAPK and Akt/PKB-signalling pathways, through Ras-Raf-Merk-Erk, Ras-PI3-K/Akt/PKB in vivo and vitro (Melillo et al, 2005; Mitsutake et al, 2006; Santoro et al, 2006). Activated Akt/PKB prevents apoptotic death in many cell types (Brunet et al, 1999). This probably explains why almost no apoptotic cell was detected in our RET/PTC mice.

In RET/PTC3 mouse thyroids, a strong labelling of phosphorylated MAPK in nuclei of the large cells and the cells in solid mass suggests a marked stimulation of the MAPK pathway. It parallels the same findings in the rat RET/PTC3-transfected thyroid cell line (Basolo et al, 2002).

Apart from these pathological features the transgenic models raise several interesting functional points. Double transgenic mice of RET/PTC3 and E7, and A2R and E7 showed that E7-mediated thyroid phenotype is dominant (Coppée et al, 1998; Portella et al, 2000). E7 oncogene acts downstream of RET/PTC3, and directly binds and inhibits RB1 protein and/or related proteins, therefore relieving their inhibition of transcription factors E2Fs (Ledent, 1996; Dyson, 1998; Helin, 1998). This could explain the scarcity of thyrocytes nuclei positive for Cyclin D1. It suggests that Cyclin D1 expression in thyroid epithelium of the E7 cells is inhibited by a negative feedback of the Cyclin D1-RB1-E2F1 axis. The cyclin D1 staining of stromal cells (not seen in WT and RET/PTC3 thyroids) is puzzling and not reported in human thyroid carcinomas (Wang et al, 2000). However, we have identified such features in human thyroid goitres, and in malignant tumours with 'E7 like' cellular features. It suggests that stromal cells get direct or indirect autocrine or paracrine signals from E7-expressing thyroid epithelium.

The activation level of the MAP kinase and Akt/PKB was different between E7 and RET/PTC3 trangenic models. E7 acts downstream of these pathways and therefore does not activate them. E7 relieves the cell of any necessity of RB phosphorylation by cyclin-dependent kinases CDK. PKB/Akt cytoplasm staining evokes the maintenance by an unknown mechanism of a weak phosphorylation, which might prevent apoptosis.

Differences between thyroid cancer prone mouse strains have been demonstrated by others (Knostman et al, 2007). In our thyroid transgenics this phenomenon might explain strain-tostrain alterations (Russell et al, 2004; Knostman et al, 2007) as well as a detectable background of thyroid neoplasia.

Nevertheless the models allow a kinetic in vivo model of the process of tumorigenesis by the oncogenes. Gene expression study by microarray technology has shown that important biological processes are differently regulated in the two tumour models: in E7 thyroid cells overexpression of cell cycle genes constitutes the most upregulated process whereas RET PTC3 thyroid cells present an upregulation of human PTC markers, of EGF-like growth factors, and extracellular remodeling genes (Burniat et al, 2008). Similarities with human PTC are observed at a young age but are incomplete. Therefore RET/PTC3 tumours are partial and transient models of human PTC. These results are now confirmed at a histological level with two different morphofunctional phenotypes: one with small cell looking like both primordial and differentiated, the other with large cells. A later study of gene expression in lasermicrodissected areas will allow to characterize the molecular phenotype of these variants.

\section{ACKNOWLEDGEMENTS}

The excellent technical assistance of Bernadette Bournonville and Chantal Degraef is greatly appreciated. The kind help of Danièle Leemans-De Vos for secretarial task is also acknowledged. 


\section{REFERENCES}

Anwar F, Emond MJ, Schmidt RA, Hwang HC, Bronner MP (2000) Retinoblastoma expression in thyroid neoplasms. Mod Pathol 13(5): $562-569$

Basolo F, Giannini R, Monaco C, Melillo RM, Carlomagno F, Pancrazi M, Salvatore G, Chiappetta G, Pacini F, Elisei R, Miccoli P, Pinchera A, Fusco A, Santoro M (2002) Potent mitogenicity of the RET/PTC 3 oncogene correlates with its prevalence in tall-cell variant of papillary thyroid carcinoma. Am J Pathol 160(1): 247-254

Baverstock K, Egloff B, Pinchera A, Ruchti C, Williams D (1992) Thyroid cancer after Chenobyl. Nature 359: $21-22$

Brandwein-Gensler MS, Wang BY, Urken ML (2004) Spindle cell transformation of papillary carcinoma: an aggressive entity distinct from anaplastic thyroid carcinoma. Arch Pathol Lab Med 128(1): $87-89$

Bronner MP, LiVolsi VA (1991) Spindle cell squamous carcinoma of the thyroid: an unusual anaplastic tumor associated with tall cell papillary cancer. Mod Pathol 4(5): 637-643

Brunet A, Bonni A, Zigmond MJ, Lin MZ, Juo P, Hu LS, Anderson MJ, Arden KC, Blenis J, Greenberg ME (1999) Akt promotes cell survival by phosphorylating and inhibiting a Forkhead transcription factor. Cell 96(6): $857-868$

Burniat A, Jin L, Detours V, Driessens N, Goffard JC, Santoro M, Rothstein J, Dumont JE, Miot F, Corvilain B (2008) Gene expression in RET/PTC3 and E7 transgenic mouse thyroids: RET/PTC3 but not E7 tumors are partial and transient models of human papillary thyroid cancers. Endocrinology 149: 5107-5117

Cetta F, Pelizzo MR, Curia MC, Barbarisi A (1999) Genetics and clinicopathological findings in thyroid carcinomas associated with familial adenomatous polyposis. Am J Pathol 155(1): 7-9

Cho JY, Sagartz JE, Capen CC, Mazzaferri EL, Jhiang SM (1999) Early cellular abnormalities induced by RET/PTC1 oncogene in thyroidtargeted transgenic mice. Oncogene 18(24): 3659-3665

Chow SM, Chan JK, Law SC, Tang DL, Ho CM, Cheung WY, Wong IS, Lau WH. (2003) Diffuse sclerosing variant of papillary thyroid carcinoma clinical features and outcome. Eur J Surg oncol 29: 446-449

Coppée F, Depoortere F, Bartek J, Ledent C, Parmentier M, Dumont JE (1998) Differential patterns of cell cycle regulatory proteins expression in transgenic models of thyroid tumours. Oncogene 17: $631-641$

Coppée F, Gérard AC, Denef JF, Ledent C, Vassart G, Dumont JE, Parmentier M (1996) Early occurrence of metastatic differentiated thyroid carcinomas in transgenic mice expressing the A2a adenosine receptor gene and the human papillomavirus type 16 E7 oncogene. Oncogene 13: 1471 - 1482

Coulonval K, Maenhaut C, Dumont JE, Lamy F (1997) Phosphorylation of the three $\mathrm{Rb}$ protein family members is a common step of the cAMP-, the growth factor, and the phorbol ester-mitogenic cascades but is not necessary for the hypertrophy induced by insulin. Exp Cell Res 233(2): $395-398$

Dumont JE, Jauniaux JC, Roger PP (1989) The cyclic AMP-mediated stimulation of cell proliferation. Trends Biochem Sci 15(2): 67-71

Dumont JE, Maenhaut C, Christophe D, Vassart G, Roger PP (2005) The phylogeny, ontogeny, anatomy and regulation of the iodine metabolizing thyroid. Thyroid disease manager chapter 1: 1-76

Dyson N (1998) The regulation of E2F by pRB-family proteins. Genes 12: $2245-2262$

Fagin JA (2002) Minireview: branded from the start-distinct oncogenic initiating events may determine tumor fate in the thyroid. Mol Endocrinol 16(5): $903-911$

Franc B, Ledent C, de Saint-Maur PP, Parmentier M (1998) Thyroid insular carcinoma. Arch Anat Cytol Pathol 46(1-2): 63-78

Fusco A, Chiappetta G, Hui P, Garcia-Rostan G, Golden L, Kinder BK, Dillon DA, Giuliano A, Cirafici AM, Santoro M, Rosai J, Tallini G (2002) Assessment of RET/PTC oncogene activation and clonality in thyroid nodules with incomplete morphological evidence of papillary carcinoma: a search for the early precursors of papillary cancer. Am J Pathol 160(6): $1941-1944$

Gérard AC, Daumerie C, Mestdagh C, Gohy S, De Burbure C, Costagliola S, Miot F, Nollevaux MC, Denef JF, Rahier J, Franc B, De Vijlder JJ, Colin IM, Many MC (2003) Correlation between the loss of thyroglobulin iodinated and the expression of thyroid-specific proteins involved in iodine metabolism in thyroid carcinomas. J Clin Endocrinol Metabol 88(10): $4977-4983$
Harach HR, Williams GT, Williams ED (1994) Familial adenomatous polyposis associated thyroid carcinoma: a distinct type of follicular cell neoplasm. Histopathology 25(6): 549-561

Helin K (1998) Regulation of cell proliferation by the E2F transcription factors. Curr Opin Genet 8: 28-35

Iuliano R, Trapasso F, Stella A, Le pira I, Melillo RM, Bruni P, Baldassarre G, Chiariotti L, Santoro M, Viglietto G, Fusco A (2000) Pivotal role of the $\mathrm{RB}$ family proteins in in vitro thyroid cells transformation. Exp Cell Res 260: $257-267$

Jhiang SM, Sagartz JE, Tong Q, Parker-Thornburg J, Capen CC, Cho JY, Xing S, Ledent C (1996) Targeted expression of the ret/PTC1 oncogene induces papillary thyroid carcinomas. Endocrinology 137(1): 375-378

Kasakov VS, Demidchik EP, Astakhova LN (1992) Thyroid cancer after Chernobyl. Nature 359: 21

Knostman KA, Jhiang SM, Capen CC (2007) Genetic alterations in thyroid cancer: the role of mouse models. Vet Pathol 44(1): 1-14

La Perle KM, Jhiang SM, Capen CC (2000) Loss of p53 promotes anaplasia and local invasion in ret/PTC1-induced thyroid carcinomas. Am J Pathol 157(2): $671-677$

Ledent C (1996) Transgenic models of human thyeoid pathologies: hyperfunctional adenoma, anaplastic cancer, differentiated cancer, hypothyroidism. Bull Mem Acad R Med Belg 151(2): 195-201

Ledent C, Marcotte A, Dumont JE, Vassart G, Parmentier M (1995) Differentiated carcinomas develop as a consequence of the thyeoid specific expression of a thyroglobulin-human papillomavirus type $16 \mathrm{E} 7$ transgene. Oncogene 10(9): 1789-1797

Melillo RM, Castellone MD, Guarino V, De Falco V, Cirafici AM, Salvatore G, Caiazzo F, Basolo F, Giannini R, Kruhoffer M, Orntoft T, Fusco A, Santoro M (2005) The RET/PTC-RAS-BRAF linear signaling cascade mediates the motile and mitogenic phenotype of thyroid cancer cells. J Clin Invest 115(4): $1068-1081$

Mitsutake N, Miyagishi M, Mitsutake S, Akeno N, Mesa Jr C, Knauf JA, Zhang L, Taira K, Fagin JA (2006) BRAF mediates RET/PTC-induced mitogen-activated protein kinase activation in thyroid cells: functional support for requirement of the RET/PTC-RAS-BRAF pathway in papillary thyroid carcinogenesis. Endocrinology 147(2): 1014-1019

Münger K, Werness BA, Dyson N, Phelps WC, Harlow E, Howley PM (1989) Complex formation of human papillomavirus E7 proteins with the retinoblastoma tumor suppressor gene product. EMBO J 8(13): 4099-4105

Nakazawa T, Kondo T, Kobayashi Y, Takamura N, Murata S, Kameyama K, Muramatsu A, Ito K, Kobayashi M, Katoh R (2005) RET gene rearrangements (RET/PTC1 and RET/PTC3) in papillary thyroid carcinomas from an iodine-rich country (Japan). Cancer 104(5): $943-951$

Nikiforov YE, Rowland JM, Bove KE, Monforte-Munoz H, Fagin JA (1997) Distinct pattern of ret oncogene rearrangements in morphological variants of radiation-induced and sporadic thyroid papillary carcinomas in children. Cancer Res 57(9): 1690-1694

Portella G, Borselli C, Santoro M, Gerbasio D, D'Armiento MR, Dumont JE, Ledent C, Rothstein JL, Vecchio G, Fusco A (2000) Human papilloma virus 16 E7 oncogene does not cooperate with RET/PTC3 oncogene in the neoplastic transformation of thyroid cells in the transgenic mice. Oncol Res 12: $347-354$

Powell Jr DJ, Russell J, Nibu K, Li G, Rhee E, Liao M, Goldstein M, Keane WM, Santoro M, Fusco A, Rothstein JL (1998) The RET/PTC3 oncogene: metastatic solid- type papillary carcinomas in murine thyroids. Cancer res 58: $5523-5528$

Powell Jr DJ, Russell JP, Li G, Kuo BA, Fidanza V, Huebner K, Rothstein JL (2001) Altered gene expression in immunogenic poorly differentiated thyroid carcinomas from RET/PTC3p53-/-. Oncogene 20: 3235-3246

Riesco-Eizaguirre G, Santisteban P (2006) A perspective view of sodium iodide symporter research and its clinical implications. Eur J Endocrinol 155(4): $495-512$

Russell JP, Engiles JB, Rothstein JL (2004) Proinflammatory mediators and genetic background in oncogene mediated tumor progression. J Immunol 172(7): 4059-4067

Russell JP, Powell DJ, Cunnane M, Greco A, Portella G, Santoro M, Fusco A, Rothstein JL (2000) The TRK-T1 fusion protein induces neoplastic transformation of thyroid epithelium. Oncogene 19(50): 5729-5735

Sagartz JE, Jhiang SM, Tong Q, Capen CC (1997) Thyroid-stimulating hormone promotes growth of thyroid carcinomas in transgenic mice with targeted expression of the ret/PTC1 oncogene. Lab Invest 76(3): $307-318$ 
Saito T, Endo T, Kavaguchi A, Ikeda M, Katoh R, Kawaoi A, Muramatsu A, Onaya $T$ (1998) Increased expression of sodium/iodide symporter in papillary thyroid carcinomas. J Clin Invest 101: 1296-1300

Santoro M, Melillo RM, Carlomagno F, Fusco A, Vecchio G (2002) Molecular mechanisms of RET activation in human cancer. Ann NY Acad Sci 963: 116-121

Santoro M, Melillo RM, Fusco A (2006) RET/PTC activation in papillary thyroid carcinoma: European Journal of Endocrinology Prize Lecture. Eur J Endocrinol 155(5): 645-653

Soravia C, Sugg SL, Berk T, Mitri A, Cheng H, Gallinger S, Cohen Z, Asa SL, Bapat BV (1999) Familial adenomatous polyposis-associated thyroid cancer: a clinical, pathological, and molecular genetics study. $A m \mathrm{~J}$ Pathol 154(1): $127-135$

Thomas GA, Bunnell H, Cook HA, Williams ED, Nerovnya A, Cherstvoy ED, Tronko ND, Bogdanova TI, Chiappetta A, Viglietto G, Pentimalli F, Salvatore G, Fusco A, Santoro M, Vecchio G (1999) High prevalence of ret/PTC rearrangements in Ukrainian and Belarussian post-Chernobyl thyroid papillary carcinomas: a strong correlation between ret/PTC3 and the solid-follicular variant. J Clin Endocrinol Metab 84: 4232-4238

Trouttet-Masson S, Selmi-Ruby S, Bernier-Valentin F, Porra V, BergerDutrieux N, Decaussin M, Peix JL, Perrin A, Bournaud C, Orgiazzi J,
Borson-Chazot F, Franc B, Rousset B (2004) Evidence for transcriptional and posttranscriptional alterations of the sodium/iodide symporter expression in hypofunctioning benign and malignant thyroid tumors. Am J Pathol 165(1): 25-34

Vergilio J, Baloch ZW, LiVolsi VA (2002) Spindle cell metaplasia of the thyroid arising in association with papillary carcinoma and follicular adenoma. Am J Clin Pathol 117(2): 199-204

Wang S, Lloyd RV, Hutzler MJ, Safran MS, Patwardhan NA, Khan A (2000) The role of cell cycle regulatory protein, cyclin D1, in the progression of thyroid cancer. Mod Pathol 13(8): 882-887

Wapnir IL, van de Rijn M, Nowels K, Amenta PS, Walton K, Montgomery K, Greco RS, Dohán O, Carrasco N (2003) Immunohistochemical profile of the sodium/iodide symporter in thyroid, breast, and other carcinomas using high density tissue microarrays and conventional sections. J Clin Endocrinol Metab 88(4): $1880-1888$

Weinberg RA (1995) The retinoblastoma protein and cell cycle control. Cell 81(3): $323-330$

Wenig BM, Thompson LD, Adair CF, Shmookler B, Heffess CS (1998) Thyroid papillary carcinoma of columnar cell type, a clinico pathologic study of 16 cases. Cancer 82: $740-753$

Williams ED (1994) Thyroid tumorigenesis. Horm Res 42(1-2): 31 - 34 